УдК 616.1-039.42

DOI 10.11603/2411-1597.2019.2.10194

\title{
ОРФАННІ ХВОРОБИ В КАРДІОЛОГІї
}

\author{
А. О. Пірожкова, О. А. Прокопович \\ ДВНЗ «Тернопільський національний медичний університет \\ імені І. Я. Горбачевського МОЗ Украӥни»
}

\begin{abstract}
Орфанні хвороби - це рідкісні уроджені або набуті захворювання, які характеризуються тяжким, хронічним та прогресуючим перебігом, супроводжуються формуванням дегенеративних змін в організмі, зниженням якості та скороченням тривалості життя хворих.

Рідкісні захворювання на сьогодні діагностують частіше завдяки впровадженню новітніх методів діагностики, що дає змогу призначити адекватне і своєчасне патогенетичне лікування таким пацієнтам. Також необхідно вивчати нові механізми серцевих захворювань та застосовувати відповідне лікування.
\end{abstract}

\section{ORPHAN DISEASES IN CARDIOLOGY}

\section{A. O. Pirogkova, O. A. Prokopovych}

\section{Horbachevsky Ternopil National Medical University}

Orphan diseases are rare congenital or acquired diseases characterized by severe, chronic course, progressive flow, accompanied by the formation of degenerative changes in the body, decreased quality and reduced life expectancy of patients.

Rare diseases are now diagnosed more often due to the introduction of the newest diagnostic methods, which enables to assign adequate and timely pathogenetic treatment to such patients. It is also necessary to study new mechanisms of heart disorders and use appropriate treatment.

Вступ. Орфанні хвороби - це рідкісні уроджені або набуті захворювання, які характеризуються тяжким, хронічним та прогресуючим перебігом, супроводжуються формуванням дегенеративних змін в організмі, зниженням якості та скороченням тривалості життя хворих і навіть становлять загрозу для їхнього життя.

Основна частина. Серед кардіологічних захворювань рідкісними вважають хворобу Такаясу, хворобу Кавасакі, міксому серця, амідоїдоз серця, хворобу Морфана, кардіоміопатію Такоцубо, уроджену відсутність перикарда, коронарний синдром X та Y, ідіопатичні аритмії. Їх рідко діагностують, проте необхідно пам'ятати про їхнє існування, для проведення диференціальної діагностики та призначення патогенетичного лікування. Часто такі пацієнти $€$ інвалідами і потребують специфічного лікування, тому перебувають на державному забезпеченні.

Хвороба Такаясу - це системне, аутоімунне захворювання, яке характеризується запальним ураженням аорти та їі основних гілок, що призводить до обліте-

() А. О. Пірожкова, О. А. Прокопович, 2019 рації судин, уповільнення або припинення кровотоку до органів [1]. У патологічний процес можуть втягуватись легенева артерія, підключична артерія, сонні артерії, клубові та стегнові артерії, проявляється захворювання у віці від 15 до 30 років життя. Однією 3 особливостей $\epsilon$ неможливість пропальпувати пульс на руках пацієнтів. Перший опис таких хворих зроблено японським лікарем Мікіто Такаясу. У стінках великих судин виникає запалення, виробляються антитіла до власних тканин, зокрема до тканин стінки артерій, це призводить до утворення гранульом у судинах. Початок хвороби Такаясу, як правило, гострий, з високою лихоманкою. Виникають загальна слабість, біль у м'язах, суглобах, зниження маси тіла, відсутність апетиту. При втягуванні в процес підключичних артерій страждають верхні кінцівки. Виникають міалгії, мерзлякуватість. Коли уражається сонна артерія, то з'являється мозкова симптоматика: мозкові інсульти, інфаркти мозку, слабоумство. При втягуванні легеневої артерії виникає легенева гіпертензія. Ураження коронарних артерій призводить до ішемії міокарда. 
Оклюзія стегнових артерій проявляється переміжною кульгавістю.

Для діагностики необхідно провести ангіографічне і ультразвукове дослідження судин.

Лікування хвороби Такаясу має декілька завдань: зменшити імунне запалення, боротьба з ішемією, лікування симптоматичної гіпертензії, серцевої недостатності, ниркової недостатності.

До хірургічного лікування вдаються при оклюзії сонних і коронарних артерій. Ушкоджені судини замінюють спеціальними протезами.

Хвороба Кавасакі - рідкісне аутоімунне захворювання, що уражає артерії різного калібру. Виникає у дітей перших років життя. Проявляється лихоманкою, висипанням на шкірі, кон'юнктивітом, ураженням слизової рота, суглобів, аденопатією. Найбільше число випадків хвороби зареєстрували в Японії. На сьогодні хвороба Кавасакі (ХК) є однією з найрозповсюдженіших причин розвитку набутих серцевих хвороб у дитячому віці. Вона розвивається на фоні спадкової схильності та впливу вірусних або бактеріальних інфекцій. Гострий васкуліт зумовлює формування аневризм коронарних артерій (КА) у 25 \% нелікованих випадків цієї хвороби. $Є$ спеціальний алгоритм діагностики цієї форми ХК. За умови значного підвищення лабораторних показників (ШОЕ $\geq 40$ мм/год і рівень С-реактивного білка $\geq 3$ мг/дл) необхідно звернути увагу на наявність анемії, тромбоцитозу, лейкоцитозу, гіпоальбумінемії тощо. Часто атипову форму ХK помилково розцінюють як септичний стан, що в подальшому зумовлює виникнення різних ускладнень, у тому числі з боку серцево-судинної системи.

Безперечно, діагноз ХК допомагає встановити ехокардіограму (ехоКГ), за допомогою якої можна кількісно оцінити розміри КА (з визначенням Z-scores для оцінки діаметра КА).

У лабораторних аналізах хворих спостерігають анемію, лейкоцитоз, протеїнурію, лейкоцитурію, підвищення ШОЕ. Лікування хвороби Кавасакі спрямоване на пригнічення запальних процесів у судинах (введенням імуноглобуліну), антикоагулянти для профілактики тромбоутворення.

Шкірні прояви синдрому Кавасакі характеризуються виникненням висипання у вигляді червоних, дрібних плям дифузного характеру, кон'юнктивіту обох очей, тріщин на губах, малинового забарвлення язика, збільшенням шийних груп лімфатичних вузлів. Прояви хвороби з боку серцево-судинної системи у вигляді тахікардії, аритмії, серцевої недостатності.
Міксома серця - це внутрішньопорожнинна пухлина серця, що характеризується доброякісним перебігом і ендокардіальним походженням [4]. Міксома серця має округлу форму і прикріплюється до внутрішньої стінки за допомогою довгої «ніжки». Найчастіше пухлина утворюється у порожнині лівого передсердя. Праве передсердя і міжпередсердна перетинка уражаються значно рідше. При ехокардіоскопії вона має вигляд рухомого новоутворення з чіткими контурами. Оскільки дане новоутворення спостерігають рідко, етіопатогенез пухлини недостатньо вивчений, проте відомо, що проліферація і міксоматозна дегенерація розвиваються з ендотелію. Міксома серця проявляється загальноклінічною картиною: слабкістю, лихоманкою, швидкою втомлюваністю, артралгією.

При відриві частини пухлинного субстрату з подальшим розповсюдженням його з течією крові розвивається емболічний синдром. Обтурація мозкових артерій проявляється короткочасною втратою свідомості, виникають транзиторні ішемічні атаки. Пухлинний ембол може утруднювати кровообіг передсердно-шлуночкового отвору і легеневого стовбура з подальшим розвитком гемодинамічних розладів і дихальної недостатності у вигляді наростаючої задишки, порушення ритму, периферійних набряків, сухого надсадного кашлю з домішками крові.

Патогномонічною ознакою міксоми в цій ситуації $\epsilon$ значне поліпшення стану хворого угоризонтальному положенні тулуба і погіршення у вертикальному. Найбільш інформативним і доступним методом візуалізації міксоми серця є ехокардіоскопія трансторакальним доступом, що дозволяє визначити локалізацію, розміри, форму новоутворення. Особливістю міксоми $є$ їі масивна васкуляризація, яку легко розпізнати при використанні дуплексного сканування серця.

Лікування міксоми серця полягає уї̈ оперативному видаленні. Для усунення ранового дефекту проводять пластику висіченої ділянки перикарда.

Ідіопатичні аритмії. У здорових молодих людей зі структурно інтактним серцем можливе виникнення таких типів шлуночкових аритмій (ША): 1) шлуночкові екстрасистолія чи парасистолія; 2) прискорений шлуночковий ритм; 3) шлуночкові тахікардії (ШТ) - мономорфні та поліморфні; 4) фібриляція шлуночків [2].

У пацієнтів із симптомними епізодами нестійких ША можливе призначення бета-блокаторів (ББ) або недигідропіридинових блокаторів кальцієвих каналів.

Синдром подовженого QT $\epsilon$ знахідкою, що клінічно може ніколи не проявлятись, проте $\epsilon$ ризиком 
виникнення шлуночкових аритмій і рекомендовано встановлення кардіовертера-дефібрилятора [3].

Синдром Бругада - це генетично детермінована каналопатія з аутосомно-домінантним типом успадкування, зумовлена мутацією генів SCN5A та GPD1-L, що спричиняє дефект альфа-субодиниці натрієвих каналів у клітинах епікарда правого шлуночка й розвиток ранньої реполяризації кардіоміоцитів [2].

Синдром Бругада (СБ) є причиною раптової смерті (PC) без структурної хвороби серця (СХC) у $20 \%$ випадків. При цьому РС виникає переважно уві сні, коли переважає активність парасимпатичної нервової системи. Як правило, першими проявами СБ $є$ синкопе чи власне РС у пацієнтів віком 35-45 років. У $20 \%$ таких пацієнтів часто реєструють інші суправентрикулярні порушення ритму. Характерним є обтяжений сімейний анамнез - випадки РС уві сні в родичів.

Виділяють такі ЕКГ-критерії СБ: 1) подовження інтервалу PR; 2) псевдоблокада правої ніжки пучка Гіса (ПНПГ); 3) елевація сегмента ST у $\mathrm{V}_{1}-\mathrm{V}_{3}$. Також описані два типи підйому сегмента ST при цьому захворюванні: «saddle-back tyре» (сідлоподібний) i «coved type» (куполоподібний).

Утім, існують фактори, які можуть спровокувати виникнення бругадоподібних змін на електрокардіограмі (ЕКГ), зокрема це гіпертермічний синдром, вживання алкоголю та приймання певних груп медикаментів (блокатори натрієвих каналів - флекаїнід, пропафенон; ББ - пропранолол; блокатори кальцієвих каналів верапаміл, ніфедипін, дилтіазем; психотропні засоби; блокатори $\mathrm{H}_{1}$-гістамінових рецепторів тощо). Тому для спростування чи підтвердження діагнозу СБ використовують фармакологічні проби з новокаїнамідом 10 мг/кг внутрішньовенно протягом 10 хв або з флекаїнідом 300-400 мг per os. Варто зауважити, що ці проби обов'язково проводять в умовах, при яких можливо в разі необхідності виконати повноцінну серцеву легеневу реанімацію (СЛР). Фармакологічну пробу вважають позитивною в таких випадках: 1) куполоподібний підйом сегмента ST; 2) поява шлуночкових екстрасистол або Шт; 3) розширення комплексу QRS >30 \% від вихідного рівня.

Специфічних симптомів для виявлення XК практично не існує. Так, відомі дві основні клінічні форми ХК - класична (повна) й атипова (неповна). Для класичної форми ХК типовим $\epsilon$ наявність гіпертермії понад 5 днів і мінімум чотири з п'яти таких симптомів: 1) двобічний кон'юнктивіт; 2) зміни на губах або в порожнині рота: «малиновий» язик, еритема чи тріщини на губах; 3) зміни на кінцівках: еритема долонь або стоп, щільний набряк кистей або стоп на 3-5-й день хвороби, лущення шкіри на кінчиках пальців на 2-3-му тижні захворювання; 4) поліморфна екзантема на тулубі без пухирців або кірочок; 5) гостра негнійна шийна лімфаденопатія (діаметр одного лімфовузла >1,5 см).

Коронарний синдром $\mathbf{X}$ (syndrome $X$ ), або мікросудинна стенокардія (smallvessel-disease), - окрема форма ішемічної хвороби серця (IXC), що характеризується наявністю у хворих стенокардії, ішемічних змін на електрокардіограмі при відсутності змін епікардіальних вінцевих артерій при проведенні коронаровентрикулографії (КВГ) [6]. Незважаючи на те, що це захворювання діагностують у 10 \% хворих з IXC, до цього часу немає одностайної думки щодо його етіології та патогенезу, недостатньо вивчені клінічні прояви та неінвазивні діагностичні критерії. За даними деяких дослідників, хворі з метаболічним синдромом (MC) мають несприятливий перебіг IXC із можливим розвитком інфаркту міокарда та коронарної смерті. Інколи тяжкі клінічні прояви, що розцінюються як ознаки нестабільної стенокардії, вимагають проведення КВГ із метою виключення тяжкого атеросклеротичного ураження вінцевих артерій. Проте інші автори відзначають досить сприятливий прогноз.

Останнім часом велику увагу в розумінні механізмів ішемії міокарда у хворих з IXC приділяють дисфункції ендотелію (ДЕ) вінцевих судин, яка може передувати розвитку атеросклерозу і сприяти його прогресу. ДЕ виявляють при всіх відомих факторах ризику виникнення серцево-судинних захворювань: артеріальній гіпертензії (АГ), гіперхолестеринемії, цукровому діабеті, курінні, надлишковій масі тіла. Однак не завжди ДЕ у хворих з ІХС асоціюється з розвитком атеросклерозу. За даними I. D. Cox і співавторів, у хворих із МС за наявності ДЕ, підтвердженої за допомогою внутрішньокоронарного введення ацетилхоліну, не виявлено атеросклеротичне ураження вінцевих артерій, верифіковане за допомогою внутрішньосудинного ультразвукового дослідження.

Феномен невідновленого кровотоку. Найважливіше значення для поліпшення прогнозу має своєчасність та повнота надання сучасного лікування, яке за рекомендаціями має включати проведення коронарографії та за необхідності - стентування коронарних судин. Після епізоду тривалого припинення кровотоку і подальшого відновлення течії крові у великих артеріях епікарда має місце значне 
структурне і функціональне ушкодження в системі мікроциркуляції, що призводить до недостатнього кровопостачання кардіоміоцитів. Таку розбіжність між очікуваним результатом і реальною клінічною ситуацією описано в літературі як феномен «ілюзії реперфузії». Внаслідок цього феномена у пацієнтів із гострим інфарктом міокарда (ГІМ), які перенесли «успішну» (в плані відновлення епікардіального кровотоку) реваскуляризацію міокарда, може спостерігатися феномен невідновленого кровотоку (ФНК), в англійському варіанті - «no-reflow». Феномен невідновленого кровотоку - не просто короткочасна подія при відновленні коронарної перфузії, а патологічний процес із прогресуючим перебігом у перші години та дні захворювання. ФНК спостерігають у понад 20 \% хворих з IMП ST після первинних черезшкірних коронарних втручань (ПЧКВ) залежно від застосовуваних методів діагностики.

Феномен сповільненого коронарного кровотоку (Coronary Slow Flow Phenomenon - CSFP), або кардіальний синдром Y (Cardiac Syndrome Y - CSY), являє собою відносно погано вивчене мікросудинне ураження коронарних артерій [7]. Його причина полягає в підвищенні опірності мікросудинного русла коронарних артерій кровотоку, що може призвести до інфаркту міокарда в стані спокою у молодих осіб. Ангіографічно виявляють уповільнення кровотоку. Здебільшого хворіють молоді чоловіки, з ожирінням, курці, які були госпіталізовані з гострим коронарним синдромом. На ЕКГ зміни можуть не виявляти, тест із навантаженням від'ємний, можуть бути зміни ЕКГ у стані спокою.

\section{СПИСОК ЛІТЕРАТУРИ}

1. Артериит Такаясу. Обзор литературы / Н. С. Гончарова, М. В. Самохвалова, А. В. Пахомов и др. // Артериальная гипертензия. - 2013. - № 6. - С. 478-486.

2. Макаров Л. М. Синдром Бругада / Л. М. Макаров // Медицина неотложных состояний. - 2008. - № 1 (14). С. 96-99.

3. Фомина И. Г. Значение альтернации зубца Т для диагностики опасных для жизни аритмий / И. Г. Фомина, А. И. Тарзиманова // Кардиология. - 2006. - № 6. - С. 90-91.

4. Балахонова Н. П. Миксома левого предсердия / Н. П. Балахонова, О. М. Драпкина // Российские медицинские вести. - 2007. - № 3. - С. 80-83.
Кардіоміопатія Такоцубо - названа так через схожість даних ангіограми лівого шлуночка (ЛШ) 3 пасткою для восьминога внаслідок акінезії верхівки і середніх сегментів Лш у поєднанні з гіперкінезією його базальних відділів [5]. Характерні ознаки захворювання: 1) гострий початок, зазвичай з розвитком болю за грудниною, який провокувався психоемоційним напруженням, зумовленим несприятливими обставинами, у жінок похилого віку; 2) наявність систолічної дисфункції ЛШ з особливою локалізацією порушень його регіонарної скоротливості, залученням середніх і дистальних відділів лш під час відсутності відповідності ділянок сегментам, які живляться певними коронарними артеріями; 3) оборотність, тобто нормалізація регіонарної скоротливості міокарда та функції ЛШ у цілому протягом декількох днів або тижнів. Назву стресова кардіоміопатія, або «синдром розбитого серця», - це захворювання отримало на основі зв'язку між ним і психологічним стресом, підвищення рівня вмісту катехоламінів у крові людей, зокрема адреналіну. Це захворювання найчастіше діагностують у жіночої половини населення, вік якої становить 40-55 років, тобто в період менопаузи. Причому в зимовий період захворювання прогресує більш часто. Спеціальних рекомендацій із лікування стрес-індукованої кардіоміопатії немає.

Висновки. Рідкісні захворювання на сьогодні діагностують частіше завдяки впровадженню новітніх методів діагностики, що дає змогу призначити адекватне і своєчасне патогенетичне лікування таким пацієнтам. Також варто вивчати нові механізми існуючих хвороб та застосовувати відповідне лікування.

5. Current state of knowledge on Takotsubo syndrome: a position statement from the task force on Takotsubo syndrome of the Heart / R. Lyon Alexander, E. Bossone, Birke, B. Schneider [et al.] // Failure Association of the European Society of Cardiology. European Journal of Heart Failure. -2016. - Vol.18. P. 8- 27

6. Gori T. Two Coronary "Orphan” Diseases in Search of Clinical Consideration: Coronary Syndromes X and Y / T. Gori, M. Fineschi // Cardiovasc. Ther. - 2011.

7. ST/T wave changes during acute coronary syndrome presentation in patients with the coronary slow flow phenomenon / N. Cutri, C. Zeitz, A. M. Kucia [et al.] // Int. J. Cardiol. - 2011. - Vol. 46. - P. 457-458. 